\title{
CHLOROPYRAMINE AND RANITIDINE AS A COMBINATION OF H1 AND H2 - ANTIHISTAMINES IN THE ADDITIVE THERAPY OF ANAPHYLAXIS
}

\author{
Hajriz Alihodžićć, Devleta Hadžić ${ }^{2}$,Nada Mladina
}

(C) 2019 by Acta Medica Saliniana ISSN 0350-364X

DOI: $10.5457 / 498$

Hajriz Alihodžićí, Devleta Hadžić 2.Nada Mladinaz

\section{Afiliations:}

1 Emergency medical service, Public Institution Health Centre 'Dr. Mustafa Šehović' Tuzla, Bosnia and Herzegovina, 2 Pediatric Clinic, Clinical University Center Tuzla, Bosnia and Herzegovina

\section{Received:}

16.04.2019.

\section{Accepted:}

01.11.2019.

Corresponding author:

Hajriz Alihodžić

Email: hajriz.a@hotmail.com

Funding: none

Competing interests: none

\begin{abstract}
Introduction: Current international guidelines recommend $\mathrm{H}_{1}$ and $\mathrm{H}_{2}$-antihistamines as a second or third- line drugs for the management of anaphylaxis.
\end{abstract}

Aim: To present positive cardiovascular and dermatological effects of Chloropyramine and Ranitidine as the combination of $\mathrm{H}_{1}$ and $\mathrm{H}_{2}$ - antihistamines in additive therapy of anaphylaxis.

Patients and methods: In a retrospective study two groups of 146 patients who met the NIAID/FAAN criteria for the diagnosis of anaphylaxis were compared. Experimental group consisted of 62 patients who received combination of Chloropyramine H1antihistamines and Ranitidine $\mathrm{H}_{2}$ - antihistamines. Control group consisted of 84 patients who received only Chloropyramine $\mathrm{H}_{1}$ - antihistamines.

Results: A statistically significant differences of diastolic pressure and heart rate $(\mathrm{p}<$ o.001), a higher values of diastolic pressure, and a lower values of heart rate in the experimental group of patients were recorded at the end of the pre- hospital treatment of anaphylaxis. The increase in the mean arterial blood pressure at the end of the treatment is higher in the experimental group compared to the initial values, with an average difference of $15 \mathrm{mmHg}$ (\%95 $\mathrm{CI}=7,95-21,95)$. Total prehospital time and time recovery of the skin urticaria and itch was shorter in the experimental group for 18 minutes (95\% CI= 11,95-25,95).

Conclusion: Positive cardiovascular effects and a faster resolving of the skin symptoms justify the use of combination Chloropyramine and Ranitidine as an additive therapy of anaphylaxis that is not life- threatening, and of a rapid progression.

Key words: $\mathrm{H}_{1}$ - antihistamines, $\mathrm{H}_{2}$ - antihistamines, additive therapy, anaphylaxis

INTRODUCTION:

Anaphylaxis is a severe, life- treatening, generalized or systemic hypersensitivity reaction[1]. International epidemiological studies concluded that the overall frequency of episodes of anaphylaxis using current data lies between 30 and 950 cases per 100.000 persons per year [2]. There are no data in Bosnia and Herzegovina on the frequency of anaphylaxis because there are no the national guidelines to primarily definy criteria needed for data recording on anaphylaxis cases and prehospital treatment. The incidence of anaphylaxis in Tuzla in the period from 2008 to 2012 was approximately 44 cases per 100.000 persons per year. Anaphylaxis is characterized by a rapid onset of reactions that may cause airway, breathing and circulation problems in patients, who initially may develop skin or mucosal changes. Only timely and appropriate therapy saves lifes, with a precondition that health care providers are competent and proficient in anaphylaxis protocol. The main cardiovacular changes during anaphylaxis are extravasation of fluids and vasodilatation, resulting in the development of distributionhypovolemic shock for circulating blood volume may decrease by as much as $35 \%$ within 10 minutes due to extravasation [3]. All life- threatening changes in patients with anaphylactic reactions are the result of chemical mediators that fill up the cytoplasm of mast cells, including histamine, and therefore it should be emphasized that intramuscular (IM) adrenaline is the first- line therapy for anaphylaxis [4]. Antihistamines are a second- line treatment for an anaphylactic reaction. The evidence to support their use is weak, but there are logical reasons for them [5]. H1- antihistamines may help inhibiting of histamine- induced vasodilatation and bronchoconstriction, but due to the needed time to act, it is unlikely that they will be effective lifesaving agent [6]. A combination of $\mathrm{H} 1$ and 
$\mathrm{H} 2$ antagonists have shown to be more effective than $\mathrm{H} 1$ antagonists alone in treatment of anaphylactic skin reactions $[7,8]$. Ranitidine and Cimetidine are the most studied, but not in a controlled studies to demonstrate the superiority of one $\mathrm{H}_{2}$ - antagonist over the other in the treatment of anaphylaxis [9].

$\mathrm{H}_{1}$ and $\mathrm{H}_{2}$ histamine receptors are present in the heart and may be involved in disturbances of cardiac rhythm that occurs during anaphylaxis. A histaminestimulated cardiac $\mathrm{H}_{1}$ receptors do not alter indices of autonomic heart rate regulation in healthy person, but on the contrary, the antagonism of the $\mathrm{H}_{2}$ receptors with Ranitidine leads to the decrease in the indices of parasympathetic ratio during the release of histamine. However, the future studies should pursue an answer [10]. Regarding additional medication for the treatment of anaphylaxis, $\mathrm{H}_{1}$ - antihistamines reduce a red itchy rush, while the addition of $\mathrm{H}_{2}$ - antihistamines makes an additive effect of about 10\%, which further reduces vascular permeability, hypotension and redness [11].

With this study we wanted to record the true extent of cardiovascular and dermatological effects from administration Chloropyramine $\mathrm{H}_{1}$ - antihistamines and Ranitidine $\mathrm{H}_{2}$ - antihistamines combination in anaphylaxises diagnosed according to the NIAID/ FAAN criteria (The National Institute of Allergy and Infectious Diseases/Food Allergy ans Anaphylaxis Network). The aim of this study is to show the benefit and positive effects of this combination on the recovery of cardiovascular symptoms and shortening the time needed for recovery of a skin symptoms, urticaria and itching, and compared to patients, who as an additive therapy received only Chloropyramine H1antihistamines without Ranitidine $\mathrm{H}_{2}$ - antihistamines.

\section{PATIENTS AND METHODS:}

A retrospective study conducted in the pre- hospital conditions in the area of Tuzla city. Data on patients collected from August 2014 to May 2018, included patients older than 12 years who received anaphylaxis treatment in the Health Center Tuzla, i.e. the emergency medical unit, and all the ambulances for the pre- hospital care. The study included patients who met the NIAID/FAAN clinical critera for the diagnosis of anaphylaxis [9].

The first experimental group consisted of patients who in the additive pre- hospital anaphylaxis therapy received combination of Chloropyramine H1antihistamines and Ranitidine $\mathrm{H}_{2}$ - antihistamines. The second, control group of patiens received only Choropyramine $\mathrm{H}_{1}$ - antihistamines in the additive prehospital anaphylaxis therapy without Ranitidine H2- antihistamines. The therapy used in the study was Chloropyramine chloride $\mathrm{H}_{1}$ - antihistamine - Synopen ampule $20 \mathrm{mg} / 2 \mathrm{ml}$ solution for injection (Pliva, Croatia) and Ranitidine chorid Hzantihistamine for intravenous aplication - Ranibos 5omg/2ml (Bosnalijek, Bosnia and Herzegovina) in the therapeutic recommended dose. We have compared and statistically analysed: SP - systolic blood pressure, DP - diastolic blood pressure, MAP - mean arterial pressure, and HR -heart rate. Three measurements were recorded: SP, DP, MAP and HR at the beginning, during, and at the end of the prehospital treatment. An evidence of a positive effect of therapy are: an increase in the SP, DP and MAP values compared to the third and first measurements, as well as the decrease in the $\mathrm{CP}$ value compared to the third and first measurements. All measurements of these values for the same patient were performed by the same medical doctor who was in charge of the pre- hospital anaphylaxis treatment. All three measurements were performed by the same blood pressure manometer. As an added parameter in the pre- hospital treatment we have compared the time needed for a skin utricaria and itching recovery between the two groups. The shorter duration of the pre- hospital anaphylaxis treatment served as an indicator of efficacy.

Ethics: The data collected in a retrospective study did not reveal the identities of patients, nor they influenced the methods and ways of treatment. As part of more extensive reserch of a pre- hospital anaphylaxis, the approval of the Institutional Ethics Committee was obtained.

Statistics: To analyse data the standard methods of a descriptive statistic were used. Numeric data are shown by the measures of central tendency and dispersion. The duration of the pre- hospital anaphylaxis treatment, as well as the difference of the mean arterial blood pressure at the beginning and the end of treatment was calculated by a confidence interval (CI 95\%). Comparison of the measured SP, DP, MAP and HR values was made based on $\chi^{2}$ table analysis. The statistical significance was defined as $\mathrm{p}<0.05$. Statistical tests were done using the SPSS 20.0 and Microsoft Excel (Microsoft Office) software package.

\section{RESULTS:}

We have collected medical data in the Health Center Tuzla of patients with acute allergic reactions who met the NIAID-FAAN clinical criteria for the diagnosis of anaphylaxis [9]. In total,146 patients with anaphylaxis have had all the necessary data that we collected and analyzed. In the first experimental group there were $\mathrm{N}=62$ patients who in the additive pre- hospital therapy received a combination of Chloropyramine $\mathrm{H}_{1}$ - antihistamines and Ranitidine $\mathrm{H}_{2}$ - anihistamines, respectively $42.5 \%$ out of the total number of patients. In the second, control group, there were $\mathrm{N}=84(57 \cdot 3 \%)$ patients who in the additive pre- hospital therapy received Chloropyramine $\mathrm{H}_{1}$ - antihistamines without Ranitidine $\mathrm{H}_{2}$ - anitihistamines. The overall ratio between male and female patients was 1.o9:1, there was no difference in gender representation between groups. There was a significant difference in age between patients $(\mathrm{p}=\mathrm{O}, 022)$. The average age in the first group was $39.31( \pm 15.67)$ years, and in the second group 
was $32.87( \pm 21.50)$ years with an average difference of 6.44 years $(\% 95 \mathrm{CI}=0.95-11.95)$. The leading causes of anaphylaxis insect stings $67.7 \%$ and drugs $17.7 \%$ in experimental group, control group $65.5 \%$ insect stings and drugs $26.2 \%$ (Table 1 )

Table 1: Causes of anaphylaxis

\begin{tabular}{|c|c|c|c|c|}
\hline \multirow{2}{*}{ Cause } & \multicolumn{2}{|c|}{ Experimental group } & \multicolumn{2}{|c|}{ Control group } \\
\hline & $\mathbf{N}$ & $\%$ & $\mathbf{N}$ & $\%$ \\
\hline Insect sting & 42 & $67 \cdot 7$ & 55 & 65,5 \\
\hline Drugs & 11 & 17,7 & 22 & 26,2 \\
\hline Food & 4 & 6,5 & 5 & 5,9 \\
\hline Unknown & 5 & 8,1 & 2 & 2,4 \\
\hline
\end{tabular}

$\mathrm{N}$ - number of patients

There were no differences in the symptoms of hypotension, near- syncope, syncope, altered mental anaphylaxis between patients' groups except for the status, chest pain, or arrhythmias.

frequency of cardiovascular symptoms involving

Table 2: Symptoms of anaphylaxis

\begin{tabular}{|c|c|c|c|c|c|}
\hline \multirow{2}{*}{ Affected organ } & \multicolumn{2}{|c|}{ Experimental group } & \multicolumn{2}{|c|}{ Control group } & \multirow[b]{2}{*}{ p-value } \\
\hline & $\mathbf{N}$ & $\%$ & $\mathbf{N}$ & $\%$ & \\
\hline Skin & 57 & 91,9 & 75 & 89,2 & 1.0 \\
\hline Cardiovascular & 21 & 33.9 & 20 & 23,8 & $\underline{0.024}$ \\
\hline Respiratory & 35 & 56.4 & 37 & 44.1 & 0.16 \\
\hline
\end{tabular}

$\mathrm{N}$ - number of patients

These symptoms were more common in the first experimental group in which cardiovascular symptoms had $21(33.9 \%)$ patients. The symptoms in the second

control group had $20(23.8 \%)$ patients and statistially significant less $(\mathrm{p}=\mathrm{O}, 024)$ (Table 2 ).

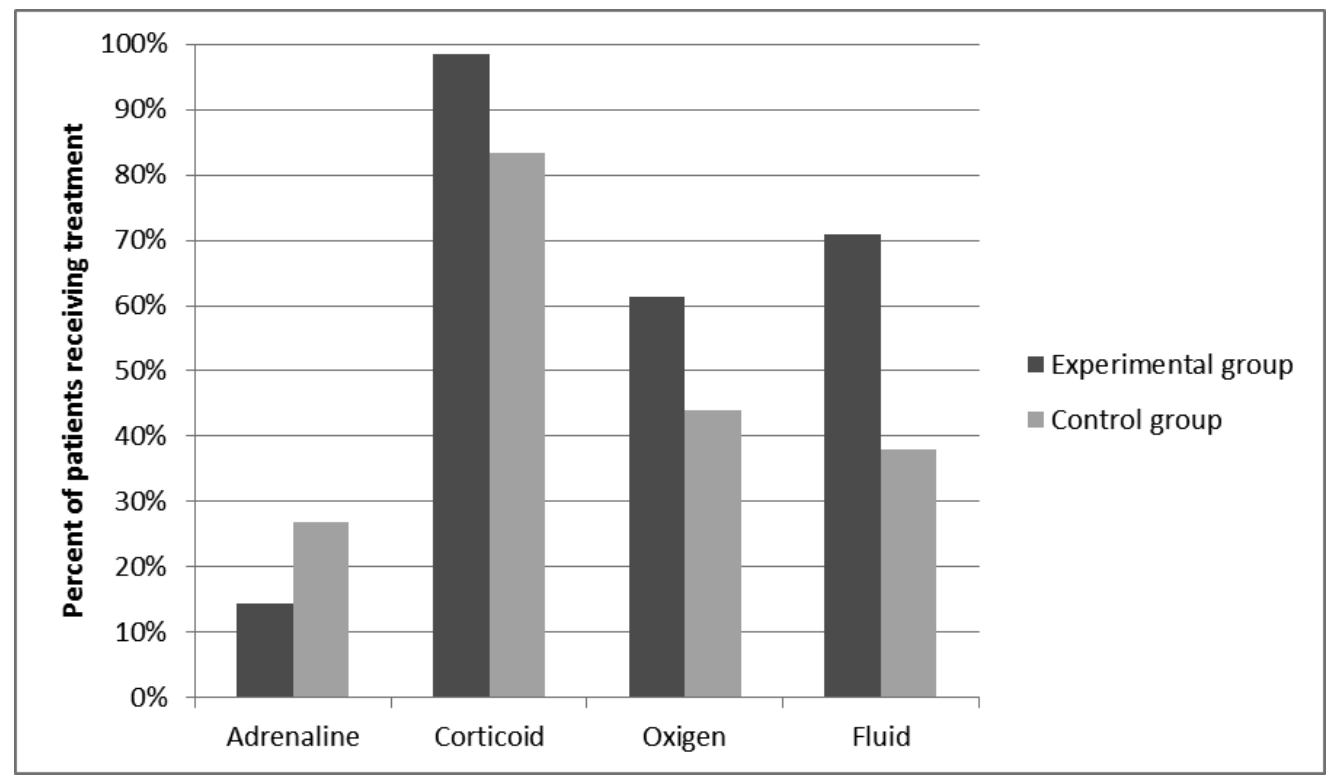

Figure 1: Drugs used by for initial treatment of anaphylaxis

For initial tretament 22 patients $(26,2 \%)$ in the control goup had adrenalin in therapy, while in the experimental grup less applied $9(14,5 \%)$. In two groups of studies corticoids were used in most patients, the experimental $98.4 \%$ and the control $83.1 \%$. Oxygen application was more common in the experimental group $61,9 \%$, the control $44,2 \%$, intravenous fluid and replenishment of the circulating volume of $70.3 \%$ patients of the experimental group, $37.3 \%$ of the control group ( Figure 1). At the first measurements of systolic pressure, diastolic pressure and hearth rate, there were no statistically significant diference between the two groups (Table 3).

Table 3: Cardiovascular clinical parameters in two observed patient groups by all measurements 


\begin{tabular}{|c|c|c|c|c|c|c|}
\hline \multirow[t]{2}{*}{ NM } & \multirow[t]{2}{*}{ Parameter } & \multicolumn{2}{|c|}{$\begin{array}{l}\text { Experimental group } \\
\qquad(\mathrm{n}=62)\end{array}$} & \multicolumn{2}{|c|}{ Control group $(n=84)$} & \multirow[t]{2}{*}{ p-value } \\
\hline & & Mean & SD & Mean & SD & \\
\hline \multirow{3}{*}{ First } & Systolic pressure $(\mathrm{mm} \mathrm{Hg})$ & 133.65 & 20.35 & 175.25 & 31.98 & 0.37 \\
\hline & Diastolic pressure $(\mathrm{mm} \mathrm{Hg})$ & 66.83 & 20.52 & 72.13 & 21.64 & 0.140 \\
\hline & Heart rate (beats per minute) & 96.19 & 38.70 & 96.19 & 24.78 & 1.0 \\
\hline \multirow{3}{*}{ Second } & Systolic pressure $(\mathrm{mm} \mathrm{Hg})$ & 119.74 & 24.18 & 108.38 & 28.92 & 0.04 \\
\hline & Diastolic pressure (mm Hg) & 70.86 & 20.35 & 65.00 & 22.85 & 0.20 \\
\hline & Heart rate (beats per minute) & 93.19 & 38.70 & 98.78 & 24.96 & 0.20 \\
\hline \multirow{3}{*}{ Third } & Systolic pressure $(\mathrm{mm} \mathrm{Hg})$ & 155.08 & 23.86 & 164.40 & 27.85 & 0.83 \\
\hline & Diastolic pressure (mm Hg) & 79.84 & 9.01 & 71.67 & 13.87 & $<0.001$ \\
\hline & Heart rate (beats per minute) & 85.16 & 10.63 & 94.82 & 17.69 & $<0.001$ \\
\hline
\end{tabular}

$\mathrm{NM}$ - number of measurement, Mean - Arithmetic Mean, $\mathrm{n}$ - number of patients,SD - standard deviation At the second measurement we have recorded a statistically significant difference $(\mathrm{p}=0.04)$ of the systolic pressure value with a higher SP value in the experimental group (Table 3).The third measurement that was performed at the end of the pre- hospital anaphylaxis treatment, we have recorded a statistically significant difference in the value of the diastolic pressure and hearth rate $(\mathrm{p}<0.001)$, which resulted in a higher DP and HR values in the experimental first group of patients (Table 3 ). As a measure of the efficacy of anaphylaxis treatment we used the recovery of the mean arterial pressure (MAP) at the end of the treatment, respectively a difference was taken at the first measurement at the beginning of the treatment, and the third measurement at the end of

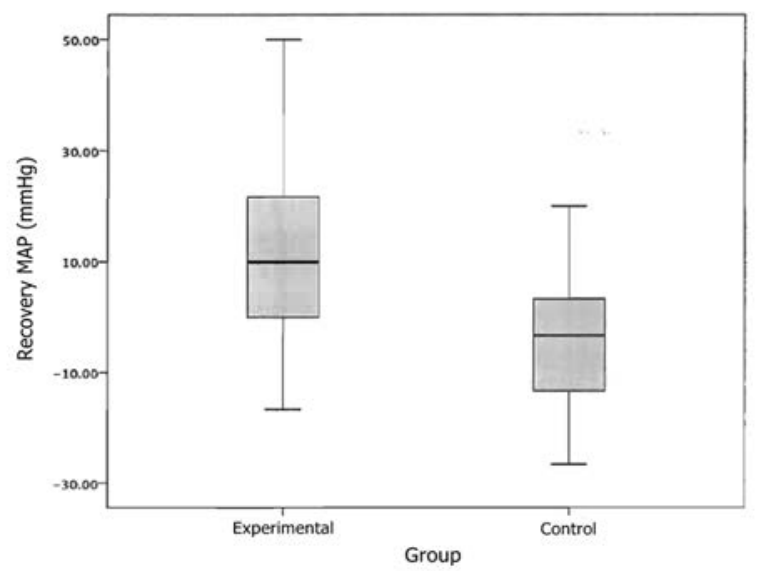

Figure 2: Comparation of mean arterial pressure recovery (MAP)

The total pre- hospital time between the patient's groups was a statistically significantly different $(\mathrm{p}<$ 0.001 ). As an additional evidence of the efficacy of the pre- hospital treatment was the time spent in recovery of a skin urticaria and itching, which in the experimental group was on average 41 (14) minutes, while the patients in control group who received only Chloropyramine H1- antihistamine without Ranitidine $\mathrm{H} 2$ - antihistamine had a longer duration of the prehospital treatment 59 (25) minutes.

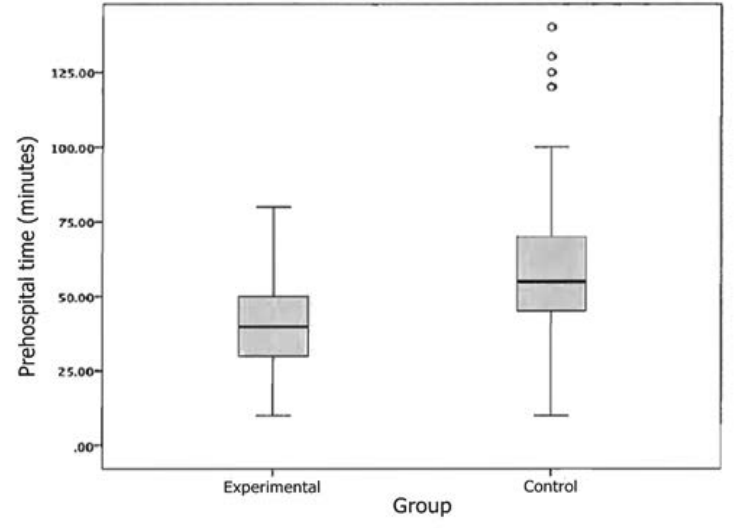

Figure 3: Comparation of the pre- hospital time and skin symptoms recovery time duration

This average difference of 18 minutes ( $95 \% \mathrm{CI}=11,95-$ 25,95) was statistically significant (Figure 3.).

\section{DISCUSSION:}

With this study, we could not find definite relevant evidence for the use of a combination $\mathrm{H}_{1}$ and $\mathrm{H}_{2}-$ antihistamines, Chloropyramine and Ranitidine in the treatment of anaphylaxis, but we have provided evidence for the possible contributions of therapeutic choice of $\mathrm{H}_{1}$ and $\mathrm{H}_{2}$ - antihistamines combination, Chloropyramine and Ranitidine, whose even minimal contribution without greater risk and side effects can be significant in the treatment of non - life threatening anaphylaxes, and whose progression is not rapid. The leading causes of anaphylaxis in the two study groups were insect sting: experimental $67,7 \%$ and drugs $17,7 \%$, control group insect sting $65,5 \%$ and drugs $26,2 \%$. The International Guidelines confirms that $\mathrm{H}_{1}-$ antihistamines and $\mathrm{H}_{2}-$ antihistamines are the second- line medications in the treatment of anaphylaxis $[12,13,14]$. These medications do not save lives and should not be the first choice in the initial or exclusive treatment of anaphylaxis, which is why the EAACI (The European Academy of Allergy and Clinical Immunology), according to the resulting evidence in studies with a small number participants, recommends 
the combination of $\mathrm{H}_{1}$ and $\mathrm{H}_{2}$ - antihistamines as the third- line medications that may relieve cutaneous symptoms [6]. Pruritus, rhinorrhea, tachycardia, and bronchospasm are caused by activation of the $\mathrm{H}_{1}$ receptors, whereas both $\mathrm{H}_{1}$ and $\mathrm{H}_{2}$ receptors mediate headache, flushing, and hypotension[15].The pathophysiologic effects of histamine in anaphylaxis have been shown to be mediated through $\mathrm{H} 1$ and $\mathrm{H}_{2}$ receptors, individually and in combination. $\mathrm{H}_{1}$ receptors mediate coronary artery vasoconstriction, wheezing, cutaneous vascular permeability, and possiblyan increase in pulserate. $\mathrm{H}_{2}$ receptors stimulate ventricular and atrial inotropy, arterial chronotropy, coronary vasodilation. Histamine activates $\mathrm{H}_{1}$ and $\mathrm{H}_{2}$ receptors in combination seem to be most potent in mediating flush, headache, increases in pulse pressure, and decreases in diastolic blood pressure[16]. By a systematic review of $\mathrm{Hz}$ - antihistamines in anaphylaxis we did not found the randomized controlled trials that would serve to compare with our study. In previous studies, the combination of $\mathrm{H}_{1}$ and $\mathrm{H}_{2}$ - antihistamines in anaphylaxis treatment, more of $80 \%$ patients were without cardiovascular or the respiratory systemic symptoms of anaphylaxis[15]. In the first experimental group of our study, a small number of patients $66.1 \%$ in anaphylaxis were without cardiovascular symptoms, in the second control group $76.2 \%$ of patients were without manifestation of cardiovasular symptoms of anaphylaxis, which is similar as in study Nurmatova et al. from 2014 [17]. The role of histamine as the main mediator in anaphylaxis is crucial in the production of symptoms and changes on the skin and mucosis that can rapidly progress towards respiratory and cardovascular collapse.

Anaphylaxes, which in its development are not always rapid and deadly, give an opportunity to use $\mathrm{H} 1$ and $\mathrm{H}_{2}$ - antihistamines that can have a positive effect on symptom regression. Endogenous histamine is a classical inflammatory and immunological mediator mainly produced by mast cells and basophils, and plays a role in allergic response, regulation of gastric- acid secretion, neurotransmittion in the central nervous system and cardiovascular function [18] Activation of either $\mathrm{H}_{1}$ or $\mathrm{H}_{2}$ subtype of histamine receptor can elicit maximal vasodilatation, but the responses differ in their sensitivity to histamine, in duration of the effect, and in the mechanism of their production [19,20].

Increased vascular permeability during anaphylaxis can result in a transfer of $50 \%$ of the intravascular fluid into the extravascular space within 10 minutes[3]. Adrenalin, oxygen and fluids are accepted first- line treatments, while antihistamines indeed may be considered second- line drugs, but they require equal valuation in their usage, especially in weighing possible side effects with their perceived benefits. The cardinal clinical feature of cardiovascular compromise during anaphylaxis is hypotension. This may be associated with clinically obvious vasodilation (erythema) or a rapid onset of shock with peripheral circulatory failure; pale, clammy and cool skin; and occasionally cardiac arrest [21]. Adrenaline is more used in the treatment of anaphylaxis the control group $26,2 \%$, experimental
$14,5 \%$,was greater but in experimental application oxigen and coticoids and above all fluid replenishment $70,3 \%$,control group $37,3 \%$. No prospective human studies have been published so far about the optimal management of anaphylaxis with adrenaline, nor is information available on dosage and bioavailability of i.m. adrenaline, when used in this condition. Even more importantly, the incidence of adverse effects after adrenaline administration in patients with anaphylactic reactions remains uncertain[22].

Anaphylaxis has been associated clinically with myocardial ischemia and with conduction defects, atrial and ventricular arrhythmias, and T-wave abnormalities $[23,24]$. A combination therapy of systemic $\mathrm{H}_{1-}$ and $\mathrm{Hz}$ - antihistamines can bring additional benefits [12]. International concensus on (ICON) anaphylaxis is that $\mathrm{H}_{1}$ - antihistamines, $\mathrm{H}_{2}$ - antihistamines, and glucocorticoids are not initial medications of choice [25]. Cardiac H1 receptors are found in the epicardial coronary vessels where they mediate vasoconstriction. Also, histamine subtype $\mathrm{Hz}_{2}$ - receptors are found in the coronary vasculature, where their vasodilating action opposes that of the $\mathrm{H}_{1}$ - receptor. Moreover, $\mathrm{H}_{2}$ - receptors are widely distributed throughout the myocardium and nodal tissue, where they exert positive inotropic and chronotropic effects [10].

The rich distribution of histamine receptors throughout the myocardium and coronary vasculature predisposes the heart to potential cardioregulatory insult in the case of the massive histamine release [26]. Use of antihistamines in the acute treatment of anaphylactic shock is directed at blocking further histamine- mediated vasodilatation and resulting haemodynamic instability, and combined $\mathrm{H}_{1}-$ and $\mathrm{H}_{2}-$ receptor blockade should be more effective than $\mathrm{H}_{1}$ blockadealone in the treatment of anaphylaxis [27]. The addition of $\mathrm{H}_{2}$ receptor antagonists to $\mathrm{H}_{1}$ antagonists during acute allergic reactions has been shown to speed resolution of symptoms[28]. However, concerns have been raised about the possible attenuation of $\mathrm{H}_{2}-$ mediated increases in inotropyand chronotopy, thereby limiting potential cardioexcitatory compensatory mechanisms [29]. Early H1-antihistamines treatment in the pre-hospital setting may decrease progression to anaphylaxis [30]. Available knowledge of the physiology of histamine release, support the preferential use of $\mathrm{H}_{1} / \mathrm{H}_{2}$ antagonist combinations in the prevention and treatment of anaphylaxis and anaphylactoid reactions [16]. In our study, a group of patients who received a combination of Chloropyramine $\mathrm{H}_{1}$ antihistamines and Ranitidine $\mathrm{H}_{2}$ - anihistamines during the treatment at the second measurement had only an increase in value of systolic pressure, while other parameters did not differ, which could be a consequence of compensatory vasoconstriction, but also the result of underdeveloped maximum extravasation. In experimental group of patients we have recorded a increase in diastolic blood pressure, a lower hearth rate, and a higher MAP at the end of the treatment, which may be associated to a greater blockage of vasodilatation, a smaller extravasation, and potentially with blocking of cardioexcitation effect, 
which, in the condition of the decrease in circulating volume excerbates histamine binding to $\mathrm{H}_{2}$ receptor in myocardioum. Combined Hiand $\mathrm{H}_{2}$ receptor blockade have been shown to be more effective that $\mathrm{H}_{1}$ receptor antagonism alone in reducing histamine-related cardiorespiratory disturbances $[16,31]$. As an illustrative and practical indicator of benefit from a combination Chloropyramine $\mathrm{H}_{1}-$ antihistamines and Ranitidine $\mathrm{H}_{2}$ - antihistamines is the best observed healing process of the skin urticaria. In the experimental group with a combination of $\mathrm{H}_{1}$ and $\mathrm{H}_{2}$ - antihistamines, the pre- hospital recovery of the skin symptoms was shorter for 18 minutes that could be associated with the competitive antagonistic effects of Chlopyramine to histamine by the reduction in the tone of smooth muscle fibers in blood vessels, and achieving reduced vasodilatation by simultaneous blockage of $\mathrm{H}_{1}$ and $\mathrm{H}_{2}$ histamine receptors, but preventing histamine binding to $\mathrm{H}_{2}$ myocardial receptors, with simultaneous.

An H2-antihistamine, administered concurrently with an H1-antihistamine, potentially contributes to decrease in flushing, headache, and other symptoms[7]. To determine the optimal management of a reaction for a patient, assessed severity needs to be integrated with the clinical context, for example, the dose of allergen, route of contact, rapidity of onset, and other intrinsic (patientrelated) and extrinsic factor [32]. There is little evidence to support the routine use of an $\mathrm{H}_{2}$-antihistamine (e.g.,ranitidine, cimetidine) for the initial treatment of an anaphylactic reaction[26]. Need to promote international guidelines on diagnosis and management of anaphylaxis among non-specialists as well as to provide adrenaline auto-injector in countries in which this device is not available in order to prevent fatal outcomes[33]. In the future, a multricentic, placebo- controlled study should be conducted among patients with anaphylaxis that was immediately assessed and treated with adrenalin, propper positioning, added oxigen and intravenous fluids before the treatment with the second line drugs such are $\mathrm{H}_{2}$ - antihistamines or placebo [15].

\section{CONCLUSION:}

The combination of Chloropyramine $\mathrm{H}_{1-}$ antihistamines and Ranitidine $\mathrm{H}_{2}$ - antihistamines should not begiven prior toadrenaline or as a potentially life- saving treatment. Positive cardiovascular effects and a faster recovery of skin symptoms justify this combination of medication in the additive anaphylaxis therapy that is not life- threatening, and of a rapid progresssion. Future multicentric, placebocontrolled trials investigating the most appropriate moment of administration the combination of $\mathrm{H} 1$ and $\mathrm{H}_{2}$ - antihistamines in anaphylaxis treatment, and evaluation of their contribution to the therapeutic results are urgently needed.

\section{REFERENCES:}

1. Johansson SG, Bieber T, Dahl R, Friedmann PS, Lanier BQ, Lockey RF, et al. Revised nomenclature for allergy for global use: Report of the Nomenclature Review Committee of the World Allergy Organization, October 2003. J Allergy Clin Immunol 2004;113(5):832-6.

2. Lieberman P, Camargo CA Jr, Bohlke K, Jick $\mathrm{H}$, Miller RL, Sheikh A, et al. Epidemiology of anaphylaxis: findings of the American College of Allergy, Asthma and Immunology Epidemiology of Anaphylaxis Working Group. Ann Allergy Asthma Immunol 2006;97(5):596-602.

3. Fisher MM. Clinical observations on the pathophysiology and treatment of anaphylactic cardiovascular collapse. Anaesth Intensive Care 1986; 14:17-21.

4. Muraro A, Roberts G, Worm M, Bilò MB, Brockow K, Fernández Rivas $\mathrm{M}$, et al. Anaphylaxis: guidelines from the European Academy of Allergy and Clinical Immunology. Allergy. 2014;69(8):1026-1045.

5. Sheikh A, Ten Broek V, Brown SG, Simons FE. H(1)-antihistamines for the treatment of anaphylaxis: Cochrane systematic review. Allergy 2007;62 (8):830-7.

6. Brown, A.F.T. Anaphylactic shock: mechanisms and treatment. Journal of Accident and Emergency Medicine, 1995; 12, pp.89-100.

7. Simons FE. Advances in $\mathrm{H1}$-antihistamines. $\mathrm{N}$ Engl J Med 2004;351:2203-17.

8. Lin RY, Schwartz LB, Curry A, Pesola GR, Knight RJ, Lee HS, et al.Histamine and tryptase levels in patients with acute allergic reactions: an emergency department-based study. J Allergy Clin Immunol 2000; 106:65-71.

9. Sampson HA, Muñoz-Furlong A, Campbell RL Ronna L,N, Adkinson NF, Bock SA, et al. Second symposium on thedefinitionand management of anaphylaxis: summary report - Second National Institute of Allergy and Infectious Disease/Food Allergy and Anaphylaxis Network symposium. J Allergy Clin Immunol 2006;117:391-7

10. Nault MA, Milne B, Parlow JL, Effects of the Selective Hrand $\mathrm{H}_{2}$ Histamine Receptor Antagonists Loratadine and Ranitidine on Autonomic Control of the Heart, Anesthesiology 2002; 96:336-41.

11. Simons FE, Anaphylaxis, J Allergy Clin Immunol. 2010;125(2 Suppl 2):S161-81.

12. Simons FER, Ebisawa M, Sanchez-Borges M, Thong BY, Worm M et al. 2015 update of the evidence base: World Allergy Organization anaphylaxis guidelines World Allergy Organ J. 2015; 8: 32 .

13. Simons FER, Ardusso LRF, Bilo MB, El-Gamal YM, Ledford DK, Ring J, et al. World Allergy Organization guidelines for the assessment 
and management of anaphylaxis. World Allergy Organ J. 2011; 4(2): 13-37.

14. Lieberman $P$, Nicklas RA, Randolph C, Oppenheimer J, Bernstein D, Bernstein J, et al. Anaphylaxis - a practice parameter update 2015. Ann Allergy Asthma Immunol. 21015; 115; 341384 .

15. Kaliner M, Sigler R, Summers R, Shelhamer JH. Effects of infused histamine: analysis of the effects of $\mathrm{H}-1$ and $\mathrm{H}-2$ receptor antagonists on cardiovascular and pulmonary responses. J Allergy Clin Immunol 1981;68:365-71.

16. Liberman $P$, The use antihistamines in the prevention and treatment of anaphylaxis and anaphylactoid reactions, J Allergy Clin Immunol, 1990, 86 (4);684-6.

17. Nurmatov UB, Rhatigan E, Simons FER, Sheikh A. H2-antihistamines for thetreatment of anaphylaxis with and without shock: a systematic review. Ann Allergy Asthma Immunol. 2014;112:126-31.

18. Ebeigbe A.B, Talabi O., Vascular Effects of Histamine. Niger. J. Physiol. Sci. 2014; 29; 007 -010 .

19. Leurs R, Smit M.J,Timmerman H. Molecular pharmacological aspects of histamine receptors. Pharmacol. Ther. 1995; 66; 413-463.

20. Hudgins P.M. Weiss G.B. Differential effects of calcium removal upon vascular smooth muscle contraction induced by norepinephrine, histamine and potassium. J Pharmacol Exp Ther. 1968; 159; 91-97.

21. Brown G.A. Cardiovascular aspects of anaphylaxis: implications for treatment and diagnosis, Curr Opin Allergy Clin Immunol. 2005;5(4):359-64.

22. Carvellini BG,Schirosa F, Ridolo E, Lippi G, Meschi T, Is adrenaline misused in anaphylaxis treatment? Experience of a large, urban Emergency Department: review of 589 cases. Signa Vitae 2016; 11(1):90-102.

23. Wasserman SI. The heart in anaphylaxis. J Allergy Clin Immunol 1986;77:663-6.

24. Alihodžić H, Ilić B, Mladina N, Mršić D, Acute coronary syndrome after hornet bite,type II Kounis syndrome-a case report, Liječ Vjesn 2013; 135:82-85.

25. Simons FE, Ardusso LR, Bilò MB, Cardona V, Ebisawa M, El-Gamal YM, et al. International consensus on (ICON) anaphylaxis. World Allergy Organ J, 7: 9.

26. Baumann G, Felix SB, Schrader J, Heidecke CD, Riess G, Erhardt WD, et al. Cardiac contractile and metabolic. effects mediated via the myocardial $\mathrm{H}_{2}$ receptor adenylate cyclase system: Characterization of two new specific $\mathrm{H}_{2}-$ receptor agonists, impromidine and dimaprit, in the guinea pig and human myocardium. Res Exp Med. 1981; 179: 81-98.
27. Nault MA, Milne B, Parlow JL. Effects of the selective $\mathrm{H}_{1}$ and $\mathrm{H}_{2}$ histamine receptor antagonists loratadine and ranitidine on autonomic control of the heart. Anesthesiology. 2002;96(2):336-341.

28. Lin RY, Curry A, Pesola, GR, Knight RJ, Lee $\mathrm{H}-\mathrm{S}$, Bakalchuk L, et al : Improved outcomes in patients with acute allergic syndromes who are treated with combined $\mathrm{H}_{1}$ and $\mathrm{H}_{2}$ antagonists. Ann Emerg Med 2000; 36: 462-8.

29. Brown AFT: Therapeutic controversies in the management of acute anaphylaxis. J Accid Emerg Med 1998; 15:89-95.

30. Kawano T, Scheuermeyer FX, Gibo K, Stenstrom $\mathrm{R}$, Rowe B, Grafstein E, H1-antihistamines Reduce Progression to Anaphylaxis Among Emergency Department Patients With Allergic Reactions. Acad Emerg Med. 2017;(6): 733-741.

31. Nurmatov UB, Rhatigan E, Simons FE, Sheikh A. Hz-antihistamines for the treatment of anaphylaxis with and without shock: a systematic review. Ann Allergy Asthma Immunol 2014; 112:126.

32. Muraro A, Fernandez-Rivas M, Beyer K, Cardona V, Clark A, Eller E, et al., The urgent need for a harmonized severity scoring system for acute allergic reactions. Allergy 2018; 73;1792-18oo.

33. Ribeiro MLKK, Chong Neto HJ, Rosario Filho NA. Diagnosis and treatment of anaphylaxis: there is an urgent needs to implement the use of guidelines. Einstein (Sao Paulo). 2017;15(4):500506.

Scan this QR code with your mobile device for instant access to the current Issue of Acta Medica Saliniana

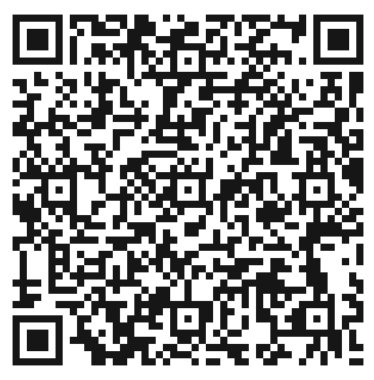

